УДК 633:631.53.027:631.878

(C) 2016

Маренич М. М., кандидат сільськогосподарських наук,

Юрченко С. О., кандидат сільськогосподарських наук

Полтавська державна аграрна академія

\title{
ПОСІВНІ ВЛАСТИВОСТІ НАСІННЯ СІЛЬСЬКОГОСПОДАРСЬКИХ КУЛЬТУР ЗАЛЕЖНО ВІД ЗАСТОСУВАННЯ СТИМУЛЯТОРІВ РОСТУ
}

\section{Рецензент - доктор сільськогосподарських наук М. Я. Шевніков}

У статті наводяться результати досліджень посівних властивостей насіння, обробленого новими препаратами гумінової природи, які виробляються компанісю «Soil-Biotics» (США). В лабораторних умовах досліджували дію стимуляторів на енергію проростання, лабораторну схожість, інтенсивність наростання органічної маси та протікання ростових прочесів. Встановлено, що обробка насіння препаратом «Seed treatment» сприяє швидшому наростанню органічної маси, активації водопоглинальної здатності насіння та інтенсифікує ростові прочеси. Відмічена позитивна дія препарату на схожість насіння за умови витримки експозиції обробка 45 днів. Застосування преnapamy «Foliar concentrate» також посилювало ростові прочеси та сприяло наростанню кореневої маси проростків.

Ключові слова: насіння, стимулятори, енертія проростання, схожість, ростові процеси.

Постановка проблеми. Численні наукові дослідження доводять, що обробка насіння перед сівбою стимулюючими ріст препаратами забезпечує швидке і дружнє проростання, збільшує стійкість рослин до таких несприятливих факторів, як нестача вологи та ураження хворобами, значно покращує конкурентні властивості культурних рослин стосовно бур'янів. У сучасному рослинництві цю проблему, здебільшого, вирішують засобами хімічного захисту, що негативно впливає на навколишнє середовище, якість продукції i, врешті-решт, шкодить здоров'ю споживача.

Аналіз останніх досліджень та публікацій, у яких започатковано розв'язання проблеми. Застосуванню гумінових речовин присвячено чимало праць, у тому числі й у вітчизняній науковій періодиці. Встановлено, що гумусові речовини сприятливо діють на проникність клітинних мембран, активізують діяльність ферментів, процеси синтезу білків, вуглеводів, підвищують інтенсивність дихання, водообміну, що в свою чергу призводить до посилення росту рослин. Особливо це відчутно, коли процеси обробки рослин препаратами починають 3 ранніх стадій розвитку. Необхідно також врахувати, що пози- тивна дія гуматів посилюється в разі екстремальності умов вирощування - нестачі вологи, засолення, дії високих або низьких температур чи надмірної концентрації добрив та отрутохімікатів $[4,6,1]$.

Дослідженнями 3 визначення впливу гуматів, які були проведені вченими Інституту сільського господарства степової зони НААН встановлено, що в разі їх використання польова схожість підвищувалась відносно контролю на 3,1-4,2\%. Застосування гуматів сприяло збільшенню виживаності рослин на 4,5-4,8 \%. Не менш важливим $\epsilon$ й те, що позитивний вплив гуматів продовжується після проростання насіння - довжина корінців кращих рослин перевищила контрольні показники на 18,8-29,2 \%, а відносно варіантуеталону з біопрепаратом «Ризогумін» - на 10,7$20,4 \%[2]$.

Застосування протруйників насіння, які мають у своїй композиції гумінові речовини, сприяє накопиченню цукрів рослинами пшениці озимої, сприяє розвитку вторинної кореневої системи, підвищує коефіцієнт кущення в рослин, що в свою чергу підвищує зимостійкість посівів [3, 7].

Застосування гумісолу та лігногумату дає змогу значно збільшити площу листової поверхні в наступних етапах розвитку рослин.

Метою досліджень було встановити вплив перспективних препаратів, створених на основі леонардиту на посівні властивості насіння та інтенсивність ростових процесів на початкових стадіях росту рослин. Для цього було сформульовано наступні завдання:

- визначити вплив препаратів «Seed treatment» та «Foliar concentrate» на енергію проростання та схожість насіння в лабораторних умовах;

- визначити вплив експозиції обробки на посівні властивості та процеси росту рослин на початкових етапах;

- провести хімічний аналіз органічної маси.

Матеріал і методика проведення досліджень. Досліди проводилися в лабораторії якості зерна Полтавської державної аграрної академії. Матеріалом для експерименту стали зразки насіння 


\section{СІЛЬСЬКЕ ГОСПОДАРСТВО. РОСЛИННИЦТВО}

культур: пшениці озимої, кукурудзи, соняшнику та сої. Насіння оброблялось рекомендованими дозами перспективних препаратів гумінового походження компанії «Soil-Biotics» (США): «Seed treatment» - 3 кг/т насіння i «Foliar concentrate» - 3 розрахунку 6 кг/га. Повторність проведення досліджень - чотирикратна. Для обробки результатів використовувалися методи дисперсійного аналізу та оцінки істотності різниці середніх за t-критерієм. Схожість визначали згідно з загальноприйнятою методикою [5].

Результати досліджень. Позитивна дія стимуляторів росту рослин, створених на основі органічної сировини, відзначається в усіх наукових дослідженнях. Дискусійним залишається лише питання норм внесення та доз препарату для обробки насіння. На наш погляд вони дуже часто є невмотивовано заниженими. Зокрема, аналіз науково-практичних рекомендацій для застосування препаратів показує, що норми застосування, які рекомендують виробник і продавець продуктів можуть різнитися в десятки разів!

Застосування гумінових препаратів для обробки насіння або внесення їх в лабораторні субстрати має позитивний ефект. Результати лабораторних аналізів свідчать про помітну тенденцію зростання таких показників початкового розвитку рослин, як масу проростків, довжину корінця та довжину стебла, які визначалися на момент визначення показника схожості насіння (табл. 1).

3 даних таблиці бачимо, що маса проростків соняшнику зросла на 52,6 \%, на пшениці озимій цей показник становив 14,3, а на кукурудзі 10,2 \%. Сдиною культурою, де обробка насіння не позначилася на масі проростка виявилася соя, однак довжина корінця була більшою на 0,34 см довшою порівняно 3 контрольним варіантом, що становить майже дев'ять відсотків.

Водночас також слід зазначити, що на пшениці озимій збільшення довжини корінця порівня- но 3 контролем становило 1,4 см або 17,7\%, а довжина стебельця проростка зросла в цьому випадку на 0,42 см, що становило близько $6 \%$.

Незначне зменшення довжини корінця в дослідах 3 кукурудзою порівняно 3 контрольним варіантом було статистично недостовірним і не перевищувало помилку досліду, а от довжина стебла зросла істотно - майже на $0,7-0,8$ см або в середньому на 20,3\%.

Про позитивну дію «Seed treatment» свідчить i візуальний огляд проростків (див. фото).

Досить цікавими виявилися результати використання обробки насіння сої з експозицією витримки обробленого насіння протягом 45 днів. Більшість рекомендацій щодо застосування препаратів гумінової природи для обробки насіння говорять про необхідність їх застосування безпосередньо перед сівбою. Проте виробник препаратів Soil-Biotics рекомендує також обробляти насіннєвий матеріал і заздалегідь.

У наших дослідах з різноякісним насінням сої спостерігалася тенденція до зростання господарсько-цінних ознак (табл. 2). Дані таблиці свідчать, що обробка препаратом позитивно вплинула на зростання схожості, особливо у насіння сої, яке характеризується низьким значенням цього показника. Збільшення довжини проростків сої становило 50,9-83,7\%. Довжина проростків пшениці зросла майже на $46 \%$. Позитивна дія експозиції пояснюється тим, що з часом препарат проникає в насіння і має час для більшого поглинання. Складники препарату сприяють поглинанню води насінням та проростками. Наступним препаратом, який рекомендується для застосування компанією «Soil-Biotics», $\epsilon$ «Foliar concentrate». Головною перевагою цього препарату $\epsilon$ його значна універсальність протягом практично всього періоду вегетації культур та унікальна кількість гумінових кислот, порівняно 3 іншими відомими препаратами.

\section{1. Результати впливу обробки насіння польових культур препаратом "Seed treatment»}

на показники розвитку рослин

\begin{tabular}{|c|c|c|c|c|}
\hline Культура & Варіант & $\begin{array}{c}\text { Середня маса } \\
\text { проростків, }\end{array}$ & $\begin{array}{c}\text { Середня довжи- } \\
\text { на корінця, см }\end{array}$ & $\begin{array}{c}\text { Довжина } \\
\text { стебла, см }\end{array}$ \\
\hline Соняшник & Контроль & 0,19 & & \\
& «Seed treatment» & $0,29^{*}$ & & \\
Соя & Контроль & 0,57 & 3,82 & \\
Пшениця озима & «Seed treatment» & 0,56 & $4,16^{*}$ & 7,55 \\
& Контроль & 0,14 & 7,91 & 7,97 \\
Кукурудза & «Seed treatment» & 0,16 & $9,31 *$ & 3,6 \\
& Контроль & 0,49 & 7,04 & $4,33^{*}$ \\
\hline
\end{tabular}

* - різниця істотна на рівні значущості - 0,05. 

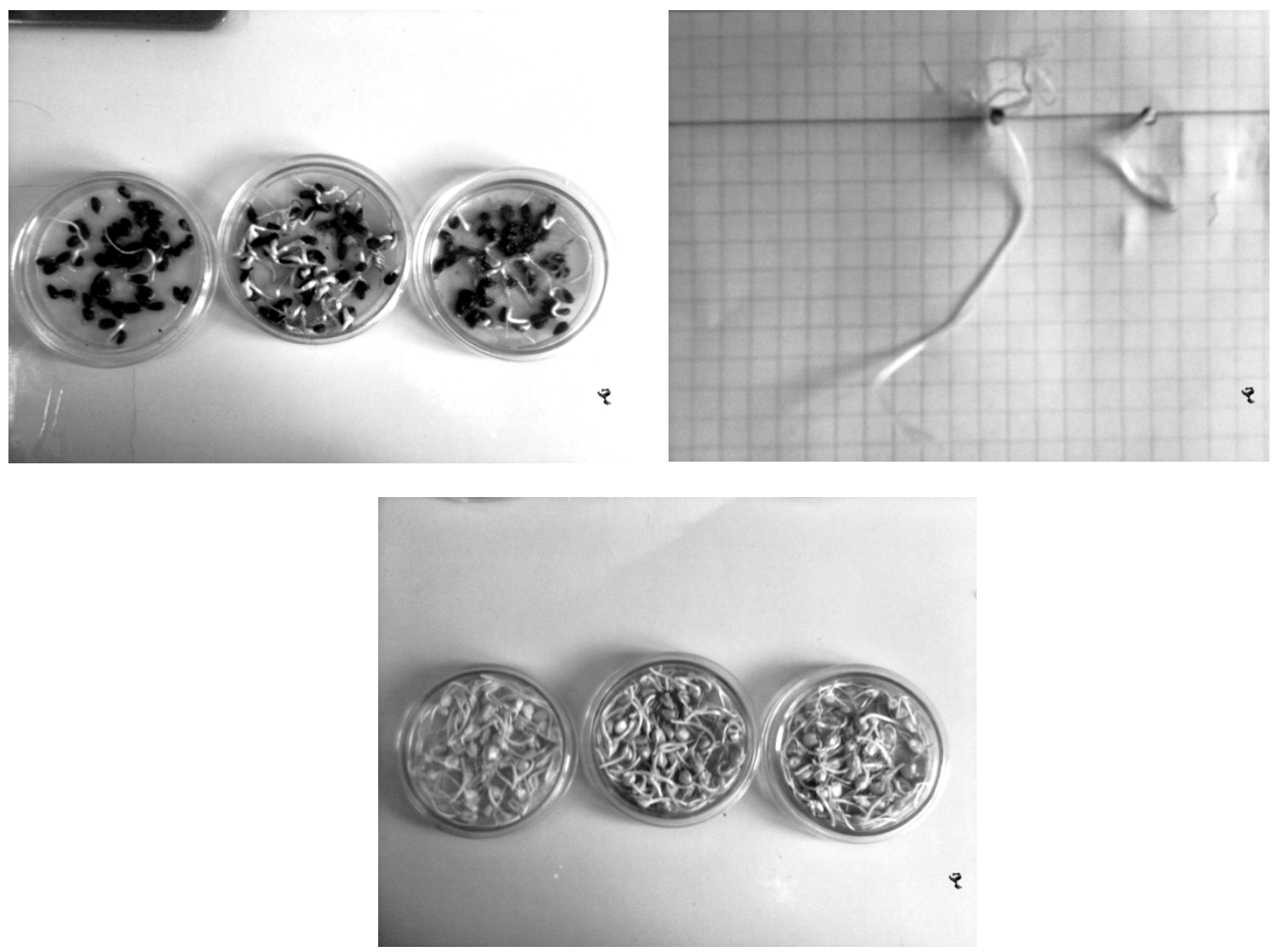

Результати обробки насіння препаратом «Seed treatment» компанії «Soil-Biotics»

2. Обробка насіння сортів сої та пшениці рекомендованими дозами препарату "Seed treatment» (тривалість експозиції- 45 днів)

\begin{tabular}{|c|c|c|c|}
\hline Варіант & Схожість, \% & $\begin{array}{c}\text { Середня довжина } \\
\text { проростків, см }\end{array}$ & Середня маса проростків, г \\
\hline \multicolumn{4}{|c|}{ Соя Алмаз } \\
\hline $\begin{array}{c}\text { Контроль } \\
\text { «Seed treatment» }\end{array}$ & 40 & $\begin{array}{c}\text { С,78 } \\
10,2^{* *}\end{array}$ & 0,17 \\
\hline \multicolumn{5}{|c|}{ Соя Антрацит } \\
\hline Контроль
\end{tabular}

** - різниця істотна на рівні значущості - 0,01 
3. Результати лабораторних випробувань преnарату "Foliar concentrate»

\begin{tabular}{|c|c|c|c|c|}
\hline Культура & Варіант & Маса рослини, г & $\begin{array}{c}\text { Довжина } \\
\text { кореня, см }\end{array}$ & $\begin{array}{c}\text { Довжина } \\
\text { стебла, см }\end{array}$ \\
\hline \multirow{2}{*}{ Пшениця озима } & Контроль & 0,17 & 7,98 & 3,82 \\
& «Foliar concentrate» & 0,18 & $8,13 *$ & 4,59 \\
\hline \multirow{2}{*}{ Кукурудза } & Контроль & 0,66 & 8,84 & 3,57 \\
& «Foliar concentrate» & 0,78 & $10,47 * *$ & $6,68 * *$ \\
\hline
\end{tabular}

* - різниця істотна на рівні значущості - 0,05 ;

** - різниця істотна на рівні значущості - 0,01.

У наших дослідах із вивчення схожості насіння на контрольному варіанті для поливу використовувалася звичайна вода, а на дослідному варіанті - водна суміш рекомендованої норми «Foliar concentrate» (табл. 3).

Зростання маси рослини пшениці озимої не перевищувало $6 \%$, але довжина стебла при цьому зростала на 20,2 \%. На кукурудзі маса рослини зростала на 18,2 \%, довжина кореня - на 18,4, а довжина стебла зростала майже на 87,1 \%!

\section{БІБЛІОГРАФІЯ}

1. Гончаренко М. П. Рекомендации по применению гумата натрия под сельскохозяйственные культуры / М. П. Гончаренко. - Днепропетровский Государственный Аграрный Университет. 1991. -22 c.

2. Ефективність передпосівної обробки насіння гороху гуматмікроелементними препаратами в умовах північної підзони Степу [Електронний ресурс] / [Мусатов А. Г., Сидоренко Ю. Я., Бочевар О. В., Ільєнко О. В.] // Бюлетень Інституту зернового господарства. - 2010. - №38. - С. 74 77. - Режим доступу : http://nbuv.gov.ua/ UJRN/bisg_2010_38_17.

3. Каленський В. П. Морозостійкість сортів пшениці озимої в осінньо-зимовий період органогенезу залежно від удобрення та передпосівної обробки насіння [Електронний ресурс] / В. П. Каленський, Л. М. Гончар // Науковий вісник Національного університету біоресурсів і природокористування України. - Серія : Агрономія. - 2012. Вип. 176. - С. 33-40. - Режим доступу :
Висновок. Обробка насіння сільськогосподарських культур препаратами, які створені на основі гумінових i фульвових кислот, сприяє підвищенню посівних властивостей насіння сільськогосподарських культур. У першу чергу це стосується сприянню розвитку кореневої системи та проростка в цілому на етапах проростання. Обробка насіння за 45 днів до висіву сприяла зростанню його схожості на 9-22 \%.

http://nbuv.gov.ua/UJRN/nvnau_agr_2012_176_6.

4. Козаренко Д. О. Застосування гуматів - перспективний метод зменшення хімічного навантаження на агроценози / Д. О. Козаренко // Карантин і захист рослин. - 2013. - №8. - С. 14-16.

5. Насіння сільськогосподарських культур. Метод визначення якості : ДСТУ 4136-2002.[Чинний від 2004.01.01]. - К. : Держспоживстандарт України, 2003. - 173 с. - (Держспоживстандарт України).

6. Сергієнко B. Рістрегулюючий та захисний ефект гумінових речовин / В. Сергієнко // Агробізнес сьогодні. - 2001. - №7. - С. 26-29.

7. Улянич O. I. Вплив передпосівної обробки насіння регуляторами росту на урожайність салату посівного [Електронний ресурс] / О. І. Улянич, В. В. Кецкало // Збірник наукових праць [Інституту біоенергетичних культур і цукрових буряків]. - 2012. - Вип. 14. - С. 356-359. Режим доступу : http://nbuv.gov.ua/UJRN/znpicb 2012 14_102. 